\title{
PENGARUH BOOK TAX DIFFERENCES TERHADAP PERTUMBUHAN LABA (STUDI EMPIRIS PADA PERUSAHAAN MANUFAKTUR YANG TERDAFTAR DI BURSA EFEK INDONESIA)
}

\author{
${ }^{1}$ Delvina Risnanda, ${ }^{2}$ Farida Khairani Lubis, ${ }^{3}$ Abdul Rasyid \\ ${ }^{1,2,3}$ Universitas Islam Sumatera Utara \\ ${ }^{1}$ delvinarisnanda3@gmail.com, ${ }^{2}$ faridakhairani@fe.uisu.ac.id, ${ }^{3}$ abdul.rasyid@fe.uisu.ac.id
}

\begin{abstract}
This research is conducted to find out the effect of temporary difference on profit growth in manufacturing companies, to find out the effect of permanent difference on profit growth in manufacturing companies, to find out the effect of book tax differences on profit growth in manufacturing companies, and to find out the effect of temporary difference, permanent difference and book tax differences on profit growth in manufacturing companies. The method used in this study is the documentation method. Documentation is the collection of data carried out with the category and classification of materials that are written and related to research problems. Data related to this study include, financial statements in the form of balance sheets and income statements from 2017-2019. And also the study of libraries used by reading books that. This study concludes that temporary difference has a positive and significant effect on profit growth in manufacturing companies listed on the Indonesia Stock Exchange in 2017-2019. Permanent Difference negatively and significantly affects profit growth in manufacturing companies listed on the Indonesia Stock Exchange in 2017-2019. Book Tax Differences has a positive and significant effect on profit growth in manufacturing companies listed on the Indonesia Stock Exchange in 2017-2019. Temporary difference, permanent difference and book tax differences simultaneously positively and significantly affect profit growth in manufacturing companies listed on the Indonesia Stock Exchange in 2017-2019.
\end{abstract}

Keywords : Temporary Difference, Permanent Difference, Book Tax Differences and Profit Growth

ABSTRAK : Penelitian ini dilakukan untuk mengetahui pengaruh temporary difference terhadap pertumbuhan laba pada perusahaan manufaktur, untuk mengetahui pengaruh permanent difference terhadap pertumbuhan laba pada perusahaan manufaktur, untuk mengetahui pengaruh book tax differences terhadap pertumbuhan laba pada perusahaan manufaktur, dan untuk mengetahui pengaruh temporary difference, permanent difference dan book tax differences terhadap pertumbuhan laba pada perusahaan manufaktur. Metode yang digunakan dalam penelitian ini adalah metode dokumentasi. Dokumentasi adalah pengumpulan data yang dilakukan dengan kategori dan klasifikasi bahan-bahan yang tertulis dan berhubungan dengan masalah penelitian. Data yang berkaitan dengan penelitian ini antara lain, laporan keuangan berupa neraca dan laporan laba rugi dari tahun 2017-2019. Dan juga studi pustaka yang digunakan dengan membaca bukubuku yang mendukung penelitian ini. Penelitian ini memberikan kesimpulan bahwa temporary difference berpengaruh positif dan signifikan terhadap pertumbuhan laba pada perusahaan manufaktur yang terdaftar di Bursa Efek Indonesia tahun 2017-2019. Permanent Difference berpengaruh negatif dan signifikan terhadap pertumbuhan laba pada perusahaan manufaktur yang terdaftar di Bursa Efek Indonesia tahun 2017-2019. Book Tax Differences berpengaruh positif dan signifikan terhadap pertumbuhan laba pada perusahaan manufaktur yang terdaftar di Bursa Efek Indonesia tahun 2017-2019. Temporary difference, permanent difference dan book tax differences secara simultan berpengaruh positif dan signifikan terhadap pertumbuhan laba pada perusahaan manufaktur yang terdaftar di Bursa Efek Indonesia tahun 2017-2019.

This study concludes that temporary difference has a positive and significant effect on profit growth in manufacturing companies listed on the Indonesia Stock Exchange in 2017-2019. Permanent Difference negatively and significantly affects profit growth in manufacturing companies listed on the Indonesia Stock Exchange in 2017-2019. Book Tax Differences has a 
positive and significant effect on profit growth in manufacturing companies listed on the Indonesia Stock Exchange in 2017-2019. Temporary difference, permanent difference and book tax differences simultaneously positively and significantly affect profit growth in manufacturing companies listed on the Indonesia Stock Exchange in 2017-2019.

Kata Kunci : Temporary Difference, Permanent Difference, Book Tax Differences dan Pertumbuhan Laba

\section{Pendahuluan}

\subsection{Latar belakang Masalah}

Book tax differences adalah perbedaan besaran laba akuntansi atau laba komersial dengan laba fiskal atau penghasilan kena pajak. Laba akuntansi adalah keuntungan atau kerugian bersih selama satu periode sebelum dikurangi beban pajak yang dihitung berdasarkan prinsip akuntansi yang berlaku umum, sedangkan laba kena pajak atau laba fiskal (rugi pajak atau rugi fiskal) adalah laba (rugi) selama satu periode yang dihitung berdasarkan peraturan yang ditetapkan oleh Otoritas Pajak atas pajak penghasilan yang terutang (Martani, 2013)".

Laba secara operasional merupakan perbedaan antara pendapatan yang timbul dari transaksi selama satu periode dengan biaya yang berkaitan dengan pendapatan tersebut (Harahap, 2013). Laba menunjukan kinerja perusahaan yang berasal dari aktivitas operasional, yakni perbandingan yang tepat atas pendapatan dan biaya yang terlihat dalam laporan laba rugi".

Dengan demikian, manajemen perusahaan akan memberikan sebuah informasi akuntansi untuk disampaikan kepada pihak stakeholder mengenai book tax differences yang mungkin dapat mempengaruhi pertumbuhan laba perusahaan satu periode kedepan. Pertumbuhan laba merupakan presentase kenaikan laba yang diperoleh perusahaan".

Penulis melakukan penelitian terhadap permasalahan ini disebabkan karena banyaknya perusahaan yang terdaftar di Bursa Efek Indonesia mengalami pertumbuhan laba yang menurun, menurunnya laba yang diperoleh perusahaan tersebut tidak terlepas dari kurangnya memperhatikan Book Tax Differences sebagaimana peraturan perpajakan yang diterapkan oleh pemerintah.

Berdasarkan latar belakang tersebut diatas menjadi dasar pemikiran bagi penulis untuk melakukan penelitian Pengaruh Book Tax Differences terhadap Pertumbuhan Laba (Studi Empiris Pada Perusahaan Manufaktur yang Terdaftar di Bursa Efek Indonesia).

\subsection{Landasan Teori}

\subsubsection{Teori Keagenan}

Teori agensi adalah hubungan atau kontrak antara principal dan agent di mana diasumsikan bahwa tiap - tiap individu semata - mata termotivasi oleh kepentingan dirinya sendiri sehingga menimbulkan konflik kepentingan antara principal dan agent (Anthony dan Govindarajan dalam Brolin, 2014)”.

\subsubsection{Perbedaan Laba Akuntansi dengan Laba Fiskal}

Martani (2013) menyatakan bahwa laba akuntansi adalah laba atau rugi bersih selama satu periode sebelum dikurangi beban pajak yang dihitung berdasarkan prinsip akuntansi yang berlaku umum, sedangkan laba kena pajak atau laba fiskal (rugi pajak atau rugi fiskal) adalah laba (rugi) selama satu periode yang dihitung berdasarkan peraturan yang ditetapkan oleh Otoritas Pajak atas pajak penghasilan yang terutang (dilunasi)".

Untuk menghitung Book Tax Differences (BTD) digunakan formula menurut Jackson (2011) dalam Saputro (2011) sebagai berikut":

$$
\begin{aligned}
& \text { BTD } \\
& =\frac{(\text { penghasilan kena pajak }- \text { laba bersih })}{\text { aktiva rata }- \text { rata }}
\end{aligned}
$$

\subsubsection{Perbedaan Permanen (Permanent Difference)}

Perbedaan permanen adalah laporan keuangan komersial dan laporan keuangan fiskal yang disebabkan oleh perbedaan pengakuan atas akun atau pos-pos yang ada. Perbedaan permanen adalah perbedaan antara laba akuntansi dengan laba pajak yang disebabkan oleh perbedaan konsep atau cara pengukuran pendapatan dan biaya. Perbedaan ini bersifat tetap artinya sekali pajak tidak memperkenankan suatu biaya atau pendapatan, maka selamanya biaya atau pendapatan tersebut harus dikeluarkan dari penghitungan pajak (Resmi, 2009)". 
Cara menghitung permanent difference adalah dengan cara menjumlah semua pos-pos perbedaan permanen dibagi dengan total aset. Permanent difference (PERM) dalam penelitian ini diukur dengan mengurangkan temporary difference (TEMP) terhadap Book Tax Difference (BTD) menurut Jackson (2011) dalam Saputro (2011) adalah sebagai berikut" :

\section{PERM = BTD - TEMP}

\subsubsection{Perbedaan Temporer (Temporary Difference)}

Deviana (2010), perbedaan temporer merupakan perbedaan waktu pengakuan penghasilan atau biaya antara pajak dan akuntansi sehingga mengakibatkan besarnya laba akuntansi lebih tinggi daripada laba pajak atau sebaliknya dalam satu periode".

Cara menghitung temporary difference adalah dengan cara menjumlah semua pos-pos perbedaan temporer dibagi dengan total aset. Temporary difference dalam penelitian ini diukur dengan membagi minus beban pajak tangguhan dengan tarif pajak yang berlaku (t) dikalikan dengan perbandingan 1 dikurangi tarif pajak kini (t) yang dibagi oleh aktiva rata-rata menurut Jackson (2011) dalam Saputro (2011) sebagai berikut" :

$$
\begin{aligned}
& \text { PerbedaanTemporer }= \\
& \frac{- \text { Beban pajak tangguhan }}{t} \times \frac{(1-t)}{\text { aktiva rata }- \text { rat } a}
\end{aligned}
$$

\subsubsection{Laporan Keuangan}

Perusahaan yang baik dan berkualitas dikarenakan tersedianya informasi yang dibutuhkan, baik informasi keuangan maupun informasi non-keuangan bagi pihak-pihak yang terlibat dalam pengambilan keputusan diperusahaan. Informasi non keuangan merupakan informasi yang tidak terdapat dalam laporan keuangan seperti persentase penawaran saham, umur perusahaan, kegiatan yang dilakukan oleh perusahaan, kebijakan pemerintah dan reputasi perusahaan (Sharralisa, 2012)".

\subsubsection{Laporan Keuangan Komersial dan Laporan Keuangan Fiskal}

Laporan keuangan umumnya terdiri atas dua macam, yaitu laporan keuangan komersial dan laporan keuangan fiskal. Menurut Suandy (2011), laporan keuangan komersial adalah laporan keuangan yang disusun sesuai Standar
Akuntansi Keuangan (SAK) yang bersifat netral dan tidak memihak. Sedangkan laporan keuangan fiskal merupakan laporan yang disusun sesuai peraturan perpajakkan dan digunakan untuk keperluan penghitungan pajak".

\subsubsection{Pertumbuhan Laba}

Pertumbuhan laba adalah salah satu informasi yang memprediksi yang sangat penting bagi para pengguna laporan keuangan yang menggambarkan prospek hasil usaha dan keadaan keuangan perusahaan di masa yang akan datang (Hanafi, 2007)".

\subsubsection{Laba}

Ghozali dan Chariri (2016:349) mengemukakan bahwa salah satu tujuan pelaporan keuangan adalah memberikan informasi keuangan yang dapat menunjukkan prestasi perusahaan dalam menghasilkan laba (earning per share). Laba adalah hasil dari suatu periode yang telah dicapai oleh perusahaan sebagaimana disebutkan dalam Statement of Financial Accounting Standards (SFAS) nomor 1, laba merupakan salah satu informasi potensial yang terkandung di dalam laporan keuangan dan yang sangat penting bagi pihak internal maupun eksternal perusahaan, untuk melakukan penaksiran earning power perusahaan di masa yang akan datang".

\subsubsection{Tujuan Laba}

Tujuan rasio profitabilitas menurut Kasmir (2014:197), yaitu:

a. Untuk mengukur atau menghitung laba yang diperoleh perusahaan dalam satu periode tertentu.

b. Untuk menilai posisi laba perusahaan tahun sebelumnya dengan tahun sekarang.

c. Untuk menilai perkembangan laba dari waktu ke waktu.

d. Untuk menilai besarnya laba bersih sesudah pajak dengan modal sendiri.

e. Untuk mengukur produktivitas seluruh dana perusahaan yang digunakan baik modal pinjaman maupun modal sendiri”.

\section{Metode Penelitian}

\subsection{Lokasi Penelitian}

Lokasi penelitian ini adalah pada perusahaan manufaktur yang terdaftar di Bursa Efek Indonesia yang diperoleh dari www.idx.co.id. 


\subsection{Objek Penelitian}

Objek penelitian ini dilakukan di perusahaan manufaktur yang terdaftar di Bursa Efek Indonesia pada tahun 2017-2019.

\subsection{Populasi dan Sampel}

Populasi adalah keseluruhan objek penelitian. Populasi yang akan menjadi pengamatan dalam penelitian ini adalah perusahaan manufaktur yang terdaftar di Bursa Efek Indonesia sub sektor logam dan sejenisnya. Pemilihan sampel dalam penelitian ini menggunakan metode purposive sampling tahun 2017-2019”.

\subsection{Operasional Variabel}

Operasionalisasi variabel menjelaskan mengenai variabel yang diteliti, konsep, indikator, satuan ukuran, serta skala pengukuran yang akan dipahami dalam operasionalisasi variabel penelitian. Sesuai dengan judul yang dipilih, maka dalam penelitian ini terdapat empat variabel, yaitu:
a. Perbedaan permanen (permanent difference $)\left(\mathrm{X}_{1}\right)$
b. Perbedaan temporer
difference) $\left(\mathrm{X}_{2}\right)$.
c. Book Tax Differences $\left(\mathrm{X}_{3}\right)$
d. Pertumbuhan Laba (Y)"

\subsection{Teknik Pengumpulan Data}

Metode yang digunakan dalam penelitian ini adalah metode dokumentasi. Dokumentasi adalah pengumpulan data yang dilakukan dengan kategori dan klasifikasi bahan-bahan yang tertulis dan berhubungan dengan masalah penelitian. Data yang berkaitan dengan penelitian ini antara lain, laporan keuangan berupa neraca dan laporan laba rugi dari tahun 2017-2019. Dan juga studi pustaka yang digunakan dengan membaca buku-buku yang mendukung penelitian ini”.

\subsection{Uji Statistik Deskriptif}

Uji statistik deskriptif digunakan untuk memberikan gambaran umum atau karakteristik data yang digunakan dalam penelitian ini. Deskripsi suatu data dapat dilihat dari nilai rata-rata (mean), standar deviasi, nilai maksimum dan minimum".

\subsection{Uji Asumsi Klasik}

Pengujian ini dilakukan untuk menguji kelayakan model regresi yang digunakan agar pengujian yang dihasilkan tidak biasa, maka harus terlebih dahulu memenuhi uji asumsi klasik (Ghozali:2017)".

\subsection{Uji Normalitas}

Pengujian normalitas data dilakukan dengan menggunakan uji one sample Kolmogorov-Smirnov dengan menggunakan taraf signifikansi 0,05. Data dinyatakan berdistribusi normal jika signifikansi lebih besar dari $5 \%$ atau $0,05 \%$

\subsection{Uji Multikoloniearitas}

Uji multikoloniearitas bertujuan untuk menguji apakah dalam model regresi ditemukan adanya korelasi antar variabel bebas".

\subsection{Uji Heteroskedastisitas}

Uji heteroskedastisitas bertujuan menguji apakah dalam model regresi terjadi ketidaksamaan variance dari residual suatu pengamatan ke pengamatan yang lain".

\subsection{Uji Hipotesis}

Pengujian hipotesis adalah metode pengambilan keputusan yang didasarkan dari analisis data, baik dari percobaan yang terkontrol maupun dari observasi (Ghozali:2017)".

\subsection{Analisis Linear Sederhana}

Analisis ini digunakan untuk menguji apakah terdapat pengaruh dua atau lebih variabel independen (explanatory) terhadap satu variabel dependen.

Model dalam penelitian ini adalah sebagai berikut :

$$
\begin{gathered}
\Delta \mathrm{NIit}=\boldsymbol{\beta 0}+\boldsymbol{\beta 1 T e m p o r e r i t}+\beta 2 \text { Permanenit } \\
+\varepsilon \mathbf{i}
\end{gathered}
$$

Keterangan :

$$
\begin{aligned}
& \beta 0 \quad \text { : Konstanta } \\
& \beta 1, \beta 2, \ldots \quad \text { : Koefisien persamaan regresi } \\
& \text { populasi } \\
& \Delta \text { NIit } \quad \text { : Pertumbuhan laba bersih } \\
& \text { perusahaan i pada tahun } \mathrm{t}
\end{aligned}
$$

\section{Hasil Penelitian}

\subsection{Analisis Statistik Deskriptif}


Tabel 1. Analisis Statistik Deskriptif

\begin{tabular}{|l|r|r|r|r|r|}
\hline & \multicolumn{1}{|c|}{$\mathrm{N}$} & \multicolumn{1}{|c|}{ Minimum } & Maximum & \multicolumn{1}{c|}{ Mean } & \multicolumn{1}{c|}{$\begin{array}{c}\text { Std. } \\
\text { Deviation }\end{array}$} \\
\hline$\triangle$ NI & 153 & 0,0011 & 1,1930 & 0,16724 & 0,203 \\
TEMP & 153 & 0,0000 & 0,0551 & 0,01169 & 0,012 \\
PERM & 153 & 0,0000 & 0,2058 & 0,01936 & 0,040 \\
BTD & 153 & 0,0003 & 0,4530 & 0,03221 & 0,061 \\
Valid N & 153 & & & & \\
(Listiwise) & & & & & \\
\hline
\end{tabular}

Berdasarkan data di atas menunjukkan bahwa jumlah observasi $(\mathrm{N})$ dari penelitian ini adalah 153 observasi. Dari 153 observasi terhadap sampel, pertumbuhan laba memiliki nilai minimal sebesar $0,0011 \%$ dan maksimal $1,193 \%$ dengan nilai rata-rata pertumbuhan laba perusahaan sampel sebesar $0,16724 \%$. Sedangkan standar deviasinya sebesar 0,203 menunjukkan variasi yang terdapat dalam variabel pertumbuhan laba yang artinya di dalam penelitian mengenai pertumbuhan laba terdapat perubahan kenaikan dan penurunan laba dalam setiap periode. Pada variabel perbedaan permanen (PERM), dengan jumlah data $(\mathrm{N})$ sebanyak 153 observasi mempunyai persentasi rata-rata sebesar $0,01936 \%$; dengan nilai minimal sebesar $0,00 \%$ dan nilai maksimal sebesar $0,2058 \%$ sedangkan standar deviasinya sebesar 0,040. Pada variabel perbedaan temporer (TEMP) mempunyai persentasi ratarata sebesar $0,01169 \%$; dengan nilai minimal sebesar $0,00 \%$ dan nilai maksimal sebesar $0,0551 \%$, sedangkan standar deviasinya sebesar 0,012. Pada variabel Book Tax Differences (BTD) mempunyai persentasi rata-rata sebesar $0,03221 \%$; dengan nilai minimal sebesar $0,0003 \%$ dan nilai maksimal sebesar $0,453 \%$, sedangkan standar deviasinya sebesar 0,061 ".

\subsection{Uji Normalitas}



Gambar 1 Grafik Normal P-P Plot of Regresion sebelum di transformasi
Sesuai dengan gambar olahan diatas dapat dilihat bahwa data menyebar jauh dari garis diagonal dan tidak mengikuti arah garis diagonal, maka model regresi tidak memenuhi asumsi normalitas. Menurut Ghozali (2007), hal ini bisa diatasi dengan melakukan transformasi logaritma (men-Ln-kan). Tujuan dari transformasi data ini adalah untuk memperoleh kesimetrian dan menstabilkan sebaran data agar menyebar disekitar garis normal, maka data berdistribusi normal".

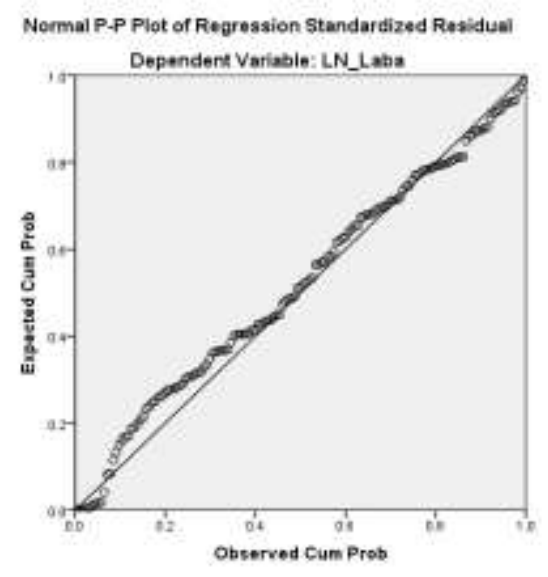

Gambar 2 Grafik Normal P-P Plot of Regresion setelah transformasi

Normal probability plot pada penelitian ini tampak pada grafik. Berdasarkan gambar diatas dapat dilihat bahwa sebaran data tersebar di sekitar garis diagonal atau tidak terpencar jauh dari garis diagonal maka dapat dikatakan bahwa persyaratan normalitas bisa terpenuhi dan hal ini berarti tidak menyalahi aturan uji asumsi klasik. Dengan demikian pengujian statistik berupa uji $\mathrm{F}$ dan uji $\mathrm{T}$ dapat dilakukan pada penelitian ini untuk menguji hipotesis".

\subsection{Uji Autokorelasi}

Tabel 2. Hasil Uji Autokorelasi Model Summary ${ }^{\mathrm{b}}$ 


\begin{tabular}{|l|l|l|l|l|l|}
\hline Model & $\mathrm{R}$ & $\begin{array}{l}\mathrm{R} \\
\text { Square }\end{array}$ & $\begin{array}{l}\text { Adjusted R } \\
\text { Square }\end{array}$ & $\begin{array}{l}\text { Std. Error } \\
\text { of the } \\
\text { Estimate }\end{array}$ & $\begin{array}{l}\text { Durbin- } \\
\text { Waston }\end{array}$ \\
\hline 1 & $0,253^{\mathrm{a}}$ & 0,064 & 0,045 & 0,1988549 & 1,893 \\
\hline
\end{tabular}

Predictors: (Constant), PERM, TEMP, BOOK

Dependent Variable: $\triangle N I$

Berdasarkan pengujian autokorelasi yang terdapat pada tabel diatas, diketahui nilai D-W sebesar 1,893\%. Maka dapat diambil kesimpulan bahwa angka tersebut berada diantara -2 sampai +2 yang berarti bahwa model regresi bebas dari autokorelasi”.

\subsection{Uji Multikolinieritas}

Tabel 3. Hasil Uji Multikoliniearitas

\begin{tabular}{|l|c|c|}
\hline Variabel & Tolerance & VIF \\
\hline TEMP & 0,994 & 1,006 \\
PERM & 0,982 & 1,018 \\
BTD & 0,987 & 1,013 \\
\hline \multicolumn{3}{|c|}{ Sumber : Data Olahan SPSS. V.20 }
\end{tabular}

Menurut Ghozali (2017) multikolinearitas terjadi jika nilai VIF melebihi angka 10. Dari tabel diatas dapat dilihat bahwa nilai VIF dari model analisis pada penelitian ini berada dibawah angka 10, maka hal ini menunjukkan

3.5. Uji Heteroskedastisitas

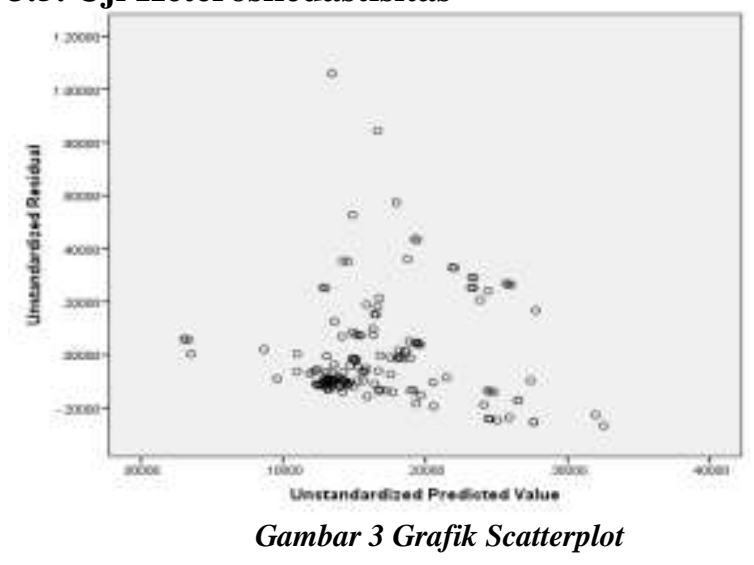

Berdasarkan gambar diatas dapat dilihat bahwa grafik scatterplot tidak membentuk pola tertentu, maka dapat disimpulkan bahwa model regresi yang digunakan adalah bebas dari heterokedastisitas". model bebas dari multikolinearitas".

\subsection{Uji T}

Tabel 4. Hasil Uji Statistik t Coefficients ${ }^{\mathrm{a}}$

\begin{tabular}{|l|l|l|l|l|l|l|}
\hline \multirow{2}{*}{ Model } & \multicolumn{2}{|l|}{$\begin{array}{l}\text { Unstandardized } \\
\text { Coefficients }\end{array}$} & $\begin{array}{l}\text { Standardized } \\
\text { Coefficients }\end{array}$ & \multirow{2}{*}{ T } & \multirow{2}{*}{ Sig } \\
\cline { 3 - 6 } & B & $\begin{array}{l}\text { Standard } \\
\text { Error }\end{array}$ & Beta & & \\
\hline \multirow{2}{*}{1} & (Constanta) & 0,125 & 0,025 & & 5,039 & 0,000 \\
& TEMP & 3,766 & 1,319 & 0,227 & 2,855 & 0,005 \\
& PERM & $-0,479$ & 0,402 & $-0,095$ & $-2,191$ & 0,024 \\
& BTD & 0,221 & 0,262 & 0,067 & 2,843 & 0,004 \\
\hline
\end{tabular}

Berdasarkan tabel diatas maka dapat dibuat persamaan regresi sebagai berikut:

$$
\Delta \mathrm{NI}=0,125+3,766 \text { TEMP }-0,479 \text { PERM }+
$$

$$
0,221 \text { Book-tax }+\mathrm{e}
$$

Dari hasil uji statistik secara parsial (uji t) menunjukkan bahwa dari 3 variabel yang dimasukkan dalam model regresi, perbedaan temporer (TEMP), perbedaan permanen (PERM) dan Book Tax Differences (BTD) signifikan mempengaruhi pertumbuhan laba $(\Delta \mathrm{NI})$. Hal ini dapat dilihat dari nilai probabilitas signifikansi untuk perbedaan temporer (TEMP) sebesar 0,005 ( $\mathrm{p}<0,05)$, nilai probabilitas signifikansi untuk perbedaan permanen (PERM) sebesar 0,024 ( $\mathrm{p}<0,05)$ dan nilai probabilitas signifikansi untuk Book Tax Differences (BTD) sebesar 0,004 ( $\mathrm{p}<0,05)$ ".

\subsection{Uji F}

Tabel 5. Hasil Uji Signifikan Simultan (Uji Statistic F) ANOVA ${ }^{b}$ 


\begin{tabular}{|c|c|c|c|c|c|}
\hline \multicolumn{6}{|c|}{ ANOVA $^{\mathrm{a}}$} \\
\hline Model & Sum of Squares & Df & Mean Square & $\mathrm{F}$ & Sig. \\
\hline Regression & 0,403 & 3 & 0,134 & 3,398 & $.019^{\mathrm{b}}$ \\
\hline $1 \quad$ Residual & 5,892 & 149 & 0,040 & & \\
\hline Total & 6,296 & 152 & & & \\
\hline \multicolumn{6}{|c|}{ a. Predictors: (Constant), PERM, TEMP, BTD } \\
\hline \multicolumn{6}{|c|}{ b. Dependent Variable: $\Delta \mathrm{NI}$} \\
\hline
\end{tabular}

Dari uji ANOVA atau F test didapat nilai $F$ hitung sebesar 3,398 dengan probabilitas 0,019. Karena probabilitas jauh lebih kecil dari 0,05 ; maka model regresi dapat digunakan untuk memprediksi pertumbuhan laba $(\Delta \mathrm{NI})$ atau dapat dikatakan bahwa perbedaan permanen (PERM), perbedaan temporer (TEMP) dan Book Tax Differences (BTD) secara bersamasama berpengaruh terhadap pertumbuhan laba $(\Delta \mathrm{NI}) "$

\subsection{Uji Determinan}

Tabel 6. Uji Determinan

\begin{tabular}{|l|l|l|l|l|}
\hline Model & R & R Square & Adjusted R Square & $\begin{array}{l}\text { Std. Error of the } \\
\text { Estimate }\end{array}$ \\
\hline 1 & $0,253^{\mathrm{a}}$ & 0,064 & 0,045 & 0,1988 \\
\hline
\end{tabular}

a. Predictors: (Constant), TEMP, PERM, BTD

b. Dependent Variable: $\Delta N I$

Dari tabel diatas diketahui bahwa besarnya Adjusted $\mathrm{R}^{2}$ adalah 0,045 . Hal ini berarti $4,5 \%$ variasi pertumbuhan laba $(\Delta \mathrm{NI})$ dapat dijelaskan oleh variasi variabel independen yaitu perbedaan temporer (TEMP), perbedaan permanen (PERM) dan Book Tax Differences (BTD) sedangkan sisanya sebesar $95,5 \%$ dijelaskan oleh sebab-sebab lain diluar model dalam penelitian ini".

\section{Kesimpulan}

a. Temporary Difference berpengaruh positif dan signifikan terhadap pertumbuhan laba pada perusahaan manufaktur yang terdaftar di Bursa Efek Indonesia tahun 2017-2019.

b. Permanent Difference berpengaruh negatif dan signifikan terhadap pertumbuhan laba pada perusahaan manufaktur yang terdaftar di Bursa Efek Indonesia tahun 2017-2019.

c. Book Tax Differences berpengaruh positif dan signifikan terhadap pertumbuhan laba pada perusahaan manufaktur yang terdaftar di Bursa Efek Indonesia tahun 2017-2019.

d. Temporary difference, permanent difference dan book tax differences secara simultan (uji
F) berpengaruh positif dan signifikan terhadap pertumbuhan laba pada perusahaan manufaktur yang terdaftar di Bursa Efek Indonesia tahun 2017-2019".

\section{DAFTAR PUSTAKA}

Ghozali, 2015. "Aplikasi Analisis Multivariat dengan Program SPSS". Semarang: Badan PenerbitUniversitas Diponegoro.

Jackson, M. 2019 Book Tax Differences and Earning Growth". University of Nevada. Terj.Lestari.

Nazir, 2016, Penelitian Kuantitatif dan Bisnis, Jakarta : Erlangga

Saputro, N. A.2014, "Pengaruh Book-Tax Differences Terhadap Pertumbuhan Laba(Studi Empiris Pada Perusahaan Manufaktur Yang Terdaftar Di BursaEfek Indonesia Tahun 2008 - 2010)". Semarang : BP UNDIP

Suwardjono.2013, Teori Akuntansi.BPFEYogyakarta

Sugiyono, 2015, PenelitianKuantitatif, Jakarta : Bumi Aksara 